\title{
Analysis of food purchase behaviour during the first wave of COVID-19 in Hungary
}

\author{
Tamás Madarász ${ }^{1}$, Enikő Kontor ${ }^{2 *}$, Emese Antal ${ }^{3}$, Gyula Kasza $^{4}$, Dávid Szakos ${ }^{5}$, Zoltán \\ Szakály 6
}

${ }^{1}$ University of Debrecen, Faculty of Economics and Business, Institute of Sports Economics and Management, Hungary H-4032, Debrecen, Böszörményi Str. 138.

madarasz.tamas@econ.unideb.hu

${ }^{2}$ University of Debrecen, Faculty of Economics and Business, Institute of Marketing and

Commerce, Hungary H-4032, Debrecen, Böszörményi Str. 138.

kontor.eniko@econ.unideb.hu

${ }^{3}$ Hungarian Platform of Diet, Physical Activity and Health, Hungary H-1062, Budapest, Andrássy Str. 61.

diet.emese.antal@gmail.com

${ }^{4}$ National Food Chain Safety Office, Hungary H-1024, Budapest, Kitaibel Pál Str. 1.

kaszagy@nebih.gov.hu

${ }^{5}$ National Food Chain Safety Office, Hungary H-1024, Budapest, Kitaibel Pál Str. 1. kszakosd@nebih.gov.hu

${ }^{6}$ University of Debrecen, Faculty of Economics and Business, Institute of Marketing and Commerce, Hungary H-4032, Debrecen, Böszörményi Str. 138.

szakaly.zoltan@econ.unideb.hu

*Corresponding author

\begin{abstract}
Coronavirus disease (SARSCoV-2) appeared in 2019 was confirmed as pandemic by the WHO on 11 March 2020. Stay-at-home order had an impact on consumers' food purchase habits, as people around the world were able to leave their homes solely in extremely severe or urgent cases. In our research, we delve into the impact of COVID-19 pandemic on consumers' food purchase habits. The research involved 3,000 consumers during the first wave of coronavirus. The sample represents the Hungarian population by gender and age. One of our objectives is to examine the motivations of the Hungarian population for food purchases during the restrictions generated by the first wave of COVID-19. To achieve the research goals, we applied multivariate statistical tools. The findings suggest that the pandemic could not change consumer attitude significantly, but the order of factors influencing purchases changed. Taste and consistent quality are basic expectations of consumers, a crisis or pandemic cannot change that. Compared to the period before restrictions, the shelf life and packaged nature of the products took precedence in the order of priority. Consumer motivation factors were organized into four well-distinguished factors: Healthy, domestic, and environmentally friendly choice;
\end{abstract}


Usual taste and quality; Reasonable price; Shelf life. Due to the lack of outstanding data during segmentation, we developed 4 segments by hierarchical cluster analysis: Health- and environmentconscious women; Price sensitive young people; Taste-oriented men; Quality-oriented intellectuals. The results confirm that food manufacturers need to be prepared for further restrictions in the future.

Keywords: Food consumer behaviour, Covid-19, Hungary, pandemia

Paper type: research paper

\section{Introduction}

Over the past two and a half decades, the number of research related to food purchase has multiplied. One of the important conclusions of these behavioural surveys is that consumers strive to choose the right quality of food during purchase. These days, however, food cannot have the main function of alleviating hunger, as a sole function, but also provide people with the nutrients they need to prevent the development of nutrition-related diseases. In addition, food should guarantee the physical improvement and mental well-being of consumers (Menrad, 2003, Roberfroid, 2000). According to Grunert and Wills (2007), persuading consumers to eat healthier is not an obvious responsibility. Their research highlighted that each person appreciates health, therefore they need to be informed about the link between diet and healthy lifestyle. Research shows that health awareness motivates consumers highly when opting for food, but the quality and taste of food are also key factors (Ares et al., 2010, Bech-Larsen et al., 2001, Grunert et al., 2000, Grunert et al., 2007, Lonneker, 2007, Patterson, 2006, Salleh et al., 2010, Urala and Lähteenmäki, 2003).

Consumers increasingly believe that food they consume contributes to their health directly (Lappalainen et al., 1998, Saher et al., 2004, Verbeke, 2006, Young, 2000).

\section{Theoretical background of food choice}

One of the main research focuses on food choice decisions is the study of consumer behaviour types related to obesity (Czeglédi and Urbán, 2010, Davis et al., 2007, Glanz et al., 1998, Serrem et al., 2020) in which the research models examine food consumers' choices. Researchers refer to two basic quantitative models when examining this decision-making process (Furst et al., 1996, Köster, 2009, Roininen et al., 1999, Szakály et al., 2020).

One is the Food Choice Questionnaire (FCQ) in which Steptoe et al. (1995) examined food choice habits through 36 statements. The authors identified nine factors that cover the motivations of those involved in the questionnaire in their food choices. These include health; mood; comfort; a sensory appeal; natural content; price; weight control; awareness and ethical considerations. Milošević et al. (2012) identified eight factors by factor analysis; compared to 
the original model, health and natural content emerged as one factor. Januszewska et al. (2011) tested the questionnaire in the populations of four countries (Belgium, Hungary, Romania, Filipinos).

Szakály et al. (2018) concluded, based on research conducted on a Hungarian sample, that for Hungarian consumers, sensory properties, price, and convenience factors (convenience of shopping and preparation) are the most important factors when choosing foods. It is an interesting result that brand awareness, i.e., the routine, has a much greater influencing effect on the choices of Hungarian consumers than in other cultures. It is backed by the survey of Markovina et al. (2015) of nine European countries, which reveals that awareness is one of the least important factors in other European cultures. At the same time, health aspects are less considered by Hungarian consumers, for example, compared to Serbian (Gagić et al., 2014), Finnish (Roos et al., 2012), Belgian, Romanian, and Filipino (Januszewska et al., 2011) consumers. Of course, there are gender differences, as the health status of food is relatively more important for women, while awareness has a greater impact on men, as confirmed by the international research mentioned above. Renner et al. (2012) stated in their research those important motivational elements were not covered by the original FCQ study. Using 78 statements in their TEMS model (The Eating Motivation Survey), they developed 15 factors (1. pleasure, 2. habits, 3. need and hunger, 4. health, 5. comfort, 6. indulgence, 7. traditional eating, 8. natural content, 9. social life, 10. price, 11. visual temptation, 12. weight control, 13. emotion regulation, 14. social norms, 15. social image), which cover, among other things, social and psychological aspects. Renner et al. (2012) based on their research on a German sample showed that participants identified motivation factors as the Liking, the Habits, the Need and the Hunger, and Health as the most common factors influencing their eating behaviour. In contrast, less important factors influencing choice are Social Image, Social Norms, and Affect Regulation. The results are consistent with the findings by Steptoe et al. (1995) based on FCQ.

Among the various models, Three Factor Eating Questionnaire (TFEQ) model (Stunkard and Messick, 1985) as the most commonly used research tool has been developed to evaluate eating behaviours of different populations (De Lauzon et al., 2004, Kavazidou et al., 2012). Originally, the survey with 51 statements was a self-assessment questionnaire whose main purpose was to analyse eating and related decision-making and behavioural processes among overweight individuals. TFEQ has been adapted by several researchers from several countries (Anglé et al., 2009, de Medeiros et al., 2017, Moreira et al., 1998). There are also shorter versions of the questionnaire that consist of fewer statements. The most common of these are the 21-item (TFEQ-R21) and 18-item (TFEQ-R18) versions, which are the most popular in 
psychology and sociology (Keller et al., 2016). Karlsson et al. (2000) developed an 18-factor version of the original three-factor dietary questionnaire (TFEQ) (TFEQ-R18). TFEQ-R18, like TFEQ and TFEQ-R21 versions, is based on three factors: cognitive restraint (CR), emotional eating (EE), and uncontrolled eating (UE). The shortened Three-Factor Eating Questionnaire (TFEQ-R18) is one of the most widely used tools for evaluating eating behaviour. Most TFEQR18 studies aim to examine overweight and obese individuals (Chong et al., 2016, Chui et al., 2019, Mostafavi et al., 2017, Romon et al., 2009), while FLVS Study Group researchers were given the same factor structure when examining individuals with normal body weight as in the previous research by Hyland et al. (1989), thus finding that the 18-statement model is also valid when examining non-obese individuals. Among their results, differences between gender and youth and adults were highlighted (Sante, 2004).

\section{Food purchase habits during the pandemic}

On March 11, 2020, the WHO confirmed coronavirus disease (SARSCoV-2) appeared in 2019, a pandemic (Tison et al., 2020). The emergence and rapid spread of COVID-19 pandemic poses a significant challenge to health systems around the world (Mattioli et al., 2020). In its global recommendation (2020), the WHO proposed that national governments shall impose restrictions to curb the spread of the infection. Despite the measures, the number of confirmed cases was already above 3.5 million on 5 May 2020, and the number of confirmed deaths exceeded 250,000 (Dong et al., 2020). Stay-at-home order have affected not only social relationships but also the functioning of businesses and corporations, as well as the physical activity and eating-buying habits of the population, as people worldwide could only leave their homes in extremely severe or urgent cases (Atalan, 2020).

A pandemic can fundamentally change food purchase habits. In EY-Future-ConsumerIndex (2020) study, it is claimed that four major trends in consumer behaviour emerged during COVID-19. These are as follows: 1. (CUT DEEP) 'Spend less.': This segment is made up particularly of people over the age of 45 whose employment situation has been most affected by the pandemic. 2. (STAY CALM, CARRY ON) 'Stay calm and don't change.': These consumers were not affected by the effects of the pandemic; therefore, they did not change their shopping habits. 3. (SAVE AND STOCKPILE) 'Save and store.': Consumers in this group are significantly concerned about the health of their families and the long-term development of their financial situation. 4. (HIBERNATE AND SPEND) 'Hibernate and Spend More!': The group consists mainly of 18-44 year olds people who have a kind of duality in terms of consumer habits. On the one hand, they are concerned about the pandemic, but only $40 \%$ said 
they purchase less often due to this fact. However, their shopping habits have changed significantly, with $46 \%$ stating that brands are more important during shopping than before. The study examined the consumer habits of 4859 individuals in the United States, Canada, the United Kingdom, France, and Germany. Overall, $42 \%$ of the respondents believed that the way they purchased had fundamentally changed as a result of COVID-19. The results of Güney and Sangün (2021) suggested that the changes were mainly related to fear of price increases, stockpiling, the purchase of usual and excessive quantities of food, food availability and a sense of security, as well as conscious food waste and natural foods and products. related to packaging.

As a result of the closures, several studies found that individuals' food choice and consumption habits have changed. According to the findings of Marinković and Lazarević (2021), the fear of the negative effects of the virus and the precautions set up for prevention influenced food purchase habits of consumers significantly. Marty et al. (2021) studied how changes in food choice motivations are related to changes in food quality during restrictions compared to the pre-pandemic period. Nine food motivations were examined: 1 . health, 2 . comfort, 3. sensory attractiveness, 4. natural content, 5. ethical concern, 6. weight control, 7. mood, 8. awareness, 9. price. Shen et al. (2020) examined the same nine motivations whether emotional eating is affected by high (73.6\%) stress levels among respondents as a result of COVID-19. The Dutch Eating Behaviour Questionnaire (DBEQ) (Strien et al., 1986) and the Food Choice Questionnaire (TFCQ) were applied in the evaluation. Rodríguez-Pérez et al. (2020) examined changes in the eating habits among the Spanish adult population during the closures. In general, out of the motivations, mood, health, comfort, and natural content were the common motivational factors. The growing popularity of digital trade has been examined in a study published by McKinsey \& Company that analysed consumer behaviour in 45 countries (Arora et al., 2020). According to the publication, online customer base growth is on average $30 \%$. Due to increased uncertainty, consumers spend most of their expenditure on basic products and reduce discretionary spending (on non-basic products and services).

Szonda Ipsos Media, Opinion and Market Research Institute ${ }^{1}$ has been measuring the effects of coronavirus epidemic on consumer behaviour in Hungary from April 2020 on a weekly basis, i.e., from the first days of the stay-at-home order. The situation emerged as a result of the coronavirus reshapes the lifestyle, habits, behaviour, and decision-making mechanisms of consumers fundamentally. As a result of the pandemic, half of the adult

\footnotetext{
1 https://www.ipsos.com/hu-hu/elerheto-valsag-hatasait-fogyasztoi-szempontbol-vizsgalo-kutatassorozat-elsoheti-riportja
} 
domestic population (52\%) do not leave their homes at all, while only one in twelve still leaves their homes as usual (8\%). In March-April 2020, Soós conducted an online questionnaire survey on changes in domestic consumer behaviour as a result of COVID-19 (Soós, 2020). In his study, he explains that consumers choose smaller stores and markets instead of larger malls, and the role of online shopping has increased. The extent of the decrease in personal purchases is wellshown by the database of the Hungarian Central Statistical Office. Based on data of the Hungarian Central Statistical Office (2021), we can see that while in March 2019 the turnover of domestic retail stores increased by $4.9 \%$, in April by $8.5 \%$ and in May by $5.0 \%$ compared to the same period of 2018, by 2020 after an increase of 3.5\% in March, the turnover of retail stores decreased by $10.2 \%$ in April and by $2.1 \%$ in May compared to 2019 (HCSO, 2021).

Our most crucial goal is to examine the motivations of the Hungarian population for food purchases during the restrictions caused by the first wave of COVID-19. In our study, we analyse whether the motivations of the Hungarian population to buy food have changed as a result of the emergency generated by the pandemic. For comparability, we assessed the prepandemic situation, which we compared with the situation in the first wave. We would like our findings to provide guidance to food producers on how to change their products, sales channels, and communications in response to the expected additional needs, in line with the changing needs of consumers.

\section{Research methodology}

\section{Sampling}

Experts from the National Food Chain Safety Office, the Institute of Marketing and Trade of the Faculty of Economics of the University of Debrecen, and the TÉT Platform conducted a survey examining the impact of the epidemiological situation on food consumption in the form of an online questionnaire during COVID-19. The sample of 3,000 people was weighted so that the sample could represent the Hungarian adult population aged 18 and older by gender and age. Data analysis was performed with SPSS mathematical-statistical analysis software. The respondents had to answer questions in connection with their pre-pandemic food shopping habits and then repeat the answer for the period of the first wave of coronavirus. The purified sample consists of 3000 items. As the number of the examined age group in Hungary is approximately 8000 thousand (HCSO, 2021) and with a 95\% confidence level and a 5\% margin of error, based on the work of Gill and Johnson (2002), the required sample size is 385 , the sample size is appropriate for the study objectives. 


\section{Structure of the questionnaire}

The questionnaire consisted of three parts. In the first block, respondents had to answer how important various factors influencing purchasing were in the pre-epidemic period. The second block of questions analysed the same factors influencing purchasing, only in the first wave of the pandemic. Factors influencing the purchase used are illustrated in Table I.

\section{Table I.}

Factors influencing purchase and their measurement $(\mathrm{N}=3000)$

In the last block of the questionnaire, we questioned about the socio-demographic characteristics of the respondents (gender, age, type of settlement, region, highest level of education completed, subjective sense of income, perceived health, and environmental awareness). Table II. shows the percentage distribution of the socio-demographic groups of the individuals involved in the survey and the population composition according to the previously mentioned two factors.

\section{Table II.}

Distribution of the sample according to the most important background variables $(\mathrm{N}=3000)$ and population composition according to representative variables

\section{Data analysis}

In order to achieve the research goals, we used both descriptive and multivariate statistical tools. Among the descriptive methods, mean, standard deviation, coefficient of variation, and skewness were calculated. We carried out exploratory factor analysis at first out of the multivariate statistical methods. The purpose of EDF was to explore what factors can influence purchasing factors during a pandemic. Afterwards, we examined the reliability of the scales used within the measurement model of the revealed latent variables, using Cronbach's alpha and composite reliability indicators. Segmentation was performed by cluster analysis, which consisted of two main steps: in the first step we determined the number of clusters / segments by hierarchical cluster analysis, then we performed the cluster analysis using K-means method in such a way that the cluster mean was left to the applied programme. Cross-tabulation analysis and simple hypothesis tests were used to examine the clusters. 


\section{Results}

\section{Examining customer behaviour before and during the first wave}

We first asked how important the aspects listed below were for respondents when purchasing food before coronavirus. The results are shown in Table III.

\section{Table III.}

Importance of purchasing factors when buying food before coronavirus $(\mathrm{N}=3000)$

The results showed that two factors reached value above 4, these included taste and consistent quality. In this case, the standard deviation and coefficient of variation are particularly low, and the skewness, especially in case of taste, is strongly negative. This means that respondents consider these aspects to be more important. This is followed by the popular and usual brand, favourable price, integration into a healthy diet and the shelf life of the food. The search for Hungarian products and local products / food from small farm is a relatively important aspect, but environmentally friendly packaging is also of medium importance. Bio / organic origin and advertising are still at the bottom of the list.

In the following, we examined how the direction of consumers' thinking about food purchases changed during coronavirus. Related data are shown in Table IV.

\section{Table IV.}

Importance of purchasing factors when buying food during coronavirus $(\mathrm{N}=3000)$

It can be clearly seen that the first two ranks did not change compared to the pre-pandemic situation. Taste and consistent quality are basic expectations of consumers, and a crisis or epidemic cannot change that. Shelf life of the food, on the other hand, has advanced three places, the mean increased, the standard deviation and coefficient of variation decreased, and consumers agree with this influencing factor to a greater extent than in the pre-pandemic period. At the same time, the popular and usual brand declined, indicating that the brand and its usual aspect are not so important to consumers during a crisis, it is easier for consumers to give them up, often out of compulsion. Similarly, the packaged product moved up the hierarchy, which typically moves with shelf life. The Hungarian origin of the product maintained its position during the pandemic, but it could not improve on the importance mean. Environmentallyfriendly packaging, trademark, organic origin, and advertisement all ranked the last places. 


\section{Factor analysis}

Based on the exploratory factor analysis, we were able to identify four factors (Table V.). During the analysis, we obtained a model with a high explanatory power of $65.093 \%$. The first, strongest factor was named 'Healthy, Domestic, and Environmentally Friendly Choices,' which explains $27.242 \%$ of the variance. High factor weights suggest that the value dimension shapes shopping habits of Hungarian consumers to a large extent and sharply separated from the others. Regarding the Skewness indicator, it can be concluded that the distribution is significantly skewed to the left (Skewness $=-0.187$ ), i.e., Hungarian consumers consider this way of thinking to be more relevant for themselves. The second factor is 'Usual taste and quality', which explains $9.919 \%$ of the variance, related to the taste of the products and their constant quality. The factor is skewed to the left (Skewness $=-0.864$ ), i.e., Hungarian consumers are more typical of these statements. The third factor is 'Favourable Price', which includes claims about product price developments. The factor explains $9.749 \%$ of the variance, and the high factor weights suggest that the dimension shapes the thinking of Hungarian consumers to a large extent. The left skewness of the factor is also expressed (Skewness $=-0.439$ ). The fourth and weakest factor is 'Shelf life' which explains $7.724 \%$ of the variance. With respect to the skewness of the factor, it can be concluded that the distribution is skewed to the left (Skewness $=-0,200$ ), i.e., this way of thinking is also considered more relevant for themselves in the study. Convincing advertisement as a factor influencing purchasing was based on several factors and appeared with a low factor weight, therefore we deleted it from the factors.

\section{Table V.}

Results of exploratory factor analysis $(\mathrm{N}=3000)$

\section{Examination of the suitability of the measurement tool}

Before segmentation, we had to test the suitability of the measurement tool for further surveys. Reliability was examined with the Cronbach's alpha index and the composite reliability (CR) index, based on which our measurement tool can be considered reliable, and reliability cannot be further increased by removing items (Cronbach, 1951, Brunner and SÜ $\beta, 2005$ ). The results of the reliability test are summarized in Table VI.

\section{Table VI.}

Reliability of the measuring instrument 


\section{Segmentation}

During segmentation, the segmentation criteria were the previously defined attitudes (factors): Healthy, domestic, and environmentally friendly choice, Usual taste and quality, Favourable price, Shelf life. Once our data proved suitable for segmentation, we determined the number of clusters by hierarchical cluster analysis and examined whether we had outliers. Since no outliers were found and the number of segments was determined in 4 clusters, we ran the cluster analysis using K-means method, during which the determination of the cluster means was left to the algorithm. The formed clusters differ significantly from each other $(p<0.01)$ based on the analysis of variance, i.e., the result of the segmentation is valid. We were able to involve a total of 2748 people in the clusters. In the following, a detailed characterization of each cluster is performed in accordance with the objectives of the research.

\section{Cluster 1 -Health and environment-conscious women}

The proportion of the group is $30.8 \%$ (847 people) among all respondents. Within the segment, women are significantly over-represented (37.4\%) and dominated by the oldest (over 60 $40.5 \%)$. Within the group, the number of $18-29$ year old and $30-39$ year people $(23.9 \%$ and $21.6 \%$, respectively) is low. The group has a higher proportion of those with vocational education / technical education (35.7\%) and high school graduates (34.5\%). More than $60 \%$ of the cluster is made up of people living in better financial conditions, who, in addition to their daily livelihood, can even save to a greater or lesser extent. Those whose income decreased significantly as a result of the pandemic (36.1\%) are in the majority, while those who 'increased compared to the past' $(16.2 \%)$ represent a smaller number in the cluster. They typically live in cities (34.1\%) and villages (32.5\%). The members of the cluster are characterized by health and environmental awareness; 'Very health conscious' (35.4\%) and 'Very environmentally conscious' (33.5\%) dominate.

This cluster is characterized by multilevel awareness, as they rated most of the motivational factors as the highest. It is also their characteristic that they monitor the shelf life, packaging, and price of the food. In addition, they typically prefer products that are already popular or usual, but also consider flavours associated with a particular product and the consistently high quality. They also make sure that these products can be easily integrated into a healthy diet. The cluster significantly overestimates the Hungarian origin and the local products / food from small farms compared to other segments. This is backed by the predominance of health- and environment-conscious individuals in the cluster. 


\section{Cluster 2 - Price sensitive young people}

The proportion of the group is $16.0 \%$, i.e., 439 people, making it the smallest cluster. The proportion of women $(15.8 \%)$ and men $(16.1 \%)$ in the segment is almost the same. The cluster is dominated by those aged 18-29 (22.0\%). In the group, people over the age of $60(11.9 \%)$ and those aged 40-59 (15.3\%) are present in low numbers. The segment is dominated by those with a 'grade 8 education' $(33.3 \%)$, while the number of people with a tertiary education is low $(13.0 \%)$. Examining their income situation, they are characterized by rather a worse financial situation. As a result of the pandemic, those who lost their previous income $(39.5 \%)$ are represented in the group in an outstanding proportion. Typically, urban residents make up the cluster (49.66\%). The group is not typically health and environmental conscious. 'Not healthconscious at all' (38.7\%) and 'Not environmentally conscious at all' (42.1\%) dominate.

For those in the cluster, the price of the products is extremely important, and advertising related to the product is not important at all. The shelf life and packaging of food is also important. They can be considered less health and environmental conscious and the high quality food is less important, as well as the bio / ecological origin, and this group is the least motivated by the Hungarian origin and the purchase from local producers.

\section{Cluster 3 - Taste-oriented men}

Based on its size, it is the second largest cluster $(27.1 \%, 744$ people) of the four. Gender is strongly dominated by men (32.8\%) while the rate of women is lower $(21.9 \%)$. Among the age groups, those aged 18-29 (34.9\%) and 30-39 (33.8\%) stand out slightly. People over the age of 60 are present in lower numbers in the group (20.4\%). The segment is dominated by a maximum of ' 8 grade education' (36.4\%). Other education groups make up the cluster in almost equal proportions. Within the group, those in the average financial situation (they can make ends meet but can save little $-31.2 \%$ ) and (Just enough to make ends meet, but unable to save - $26.6 \%$ ) play a decisive role. Within the segment, the majority are those whose income increased during the pandemic $(35.1 \%)$. According to the place of residence, the population of the capital (28.8\%), the inhabitants of the village (27.2\%) and the city $(25.9 \%)$ occur in almost the same proportion within the group. In the group, 'Mostly not health-conscious' (36.1\%) and 'Mostly not environmentally conscious' (45.0\%) people stand out in the group.

For those in the cluster, convincing advertisements are not important at all, but the taste and enjoyment value associated with the products is important. It is not important, either, that the product they buy is packaged, and it is less characteristic to pay attention to the environmentally friendly characteristics of the product they buy. The health factor of the 
product as well as its organic/ecological origin are not considered when making a purchase decision.

\section{Cluster 4-Quality-oriented intellectuals}

According to the subjective sense of income, those with slightly better income than average (they make a living from it, but they can save little -36.3\%), and those with much better income than average (they make a good living from it and can save $-32.7 \%$ ) dominate in the group. The group was over-represented by those whose income increased during the pandemic compared to the previous period (35.1\%). Within the group, the residents of the capital $(28.5 \%)$, those living in the village (26.1\%) and the city (24.5\%) are almost equally represented. 'Mostly not health-conscious' (27.9\%) and 'Very health-conscious' (26.1\%) appear in the cluster in almost the same proportion. This duality can also be observed when examining subjective environmental awareness.

Convincing advertisement related to the product, or favourable or discount price are less important, which may be related to better financial situation. Typically, it is the flavour associated with the product and consistent quality that influence them when shopping. To a lesser extent, but the packaged and durable nature of the product they want to buy is also important, however, environmentally friendly packaging is moderately important. Slight brand loyalty characterizes the segment, while integration into a healthy diet is somewhat more important than moderate.

\section{Discussion}

In our study, we undertook to present the influencing effect of the restrictions experienced during the first wave of COVID-19 on food choice and food purchase habits of Hungarian consumers. We found that the pandemic could not change consumer thinking, however, the order of some factors changed. Compared to the period before closure, the shelf life and packaged nature of the products are those that came first in order of priority. This result is consistent with the results of Güney and Sangün (2021), where the authors found that the mode of product packaging influenced food motivation significantly during the pandemic. According to research by EIT-Food (2020), since the outbreak of COVID-19, 33\% of consumers have paid more attention to the packaging of the product they intend to choose. However, while in our study packaging was an important factor mainly during the pandemic due to the shelf life of food, in the EIT-Food (2020) research, the need for environmentally conscious packaging also appeared to a minimal extent. In our research, the issue of environmental awareness was 
somewhat pushed into the background during the pandemic period. The weight of environmental sustainability in food packaging also appears to be declining compared to the pre-pandemic period, according to an IFIC (2021) study, but their research shows that more than half of consumers still consider environmentally friendly packaging important. Of course, packaging is also related to the shelf life of the products. Fear of this can also be observed in the IFIC (2021) Food and Health Survey, with $40 \%$ of consumers being worried about the early expiry of the shelf life of the food they buy.

Examining customer behaviour in the pre-pandemic period, as well as during the first wave of the epidemic, 'product-related flavours' aspect was the most important to consumers. This result is consistent with a previous study by Glanz et al. (1998), where the authors suggest that people are more likely to choose foods during purchase, they find delicious. This kind of perception can also be observed in the IFIC (2021) study, as $82 \%$ of those surveyed identified taste as the strongest motivation to buy. Although the value of motivation for product taste decreased compared to the previous year, it is still the factor that most influential regarding consumers' final decision. This was followed by the price of the products $(66 \%)$, their health property (58\%), the convenience of shopping (52\%) and the environmental sustainability of the products $(31 \%)$. In our study, the role of brand loyalty decreased during the pandemic, which is consistent with the study by Arora et al. (2020). According to their results, when consumers could not find their preferred product (s) in their usual and popular store due to the pandemic, they changed their purchasing behaviour and other brand (s) or store (s).

According to EIT-Food (2020) research, the persistently favourable prices and availability of products appear to be re-evaluating, and in the post-pandemic period, factors related to the convenience of food purchases and food prices come to the fore. According to our study, the motivational power of the special price and the persistently low price of products decreased overall, but the influencing role of food prices in certain social strata strengthened. This group includes particularly young people who lose their jobs and incomes.

Hungarian origin maintained its position during the pandemic. According to Hobbs (2020), it seems likely that demand for local foods after COVID-19 will increase in the short to medium term, as the importance of local foods is a well-established consumer trend that according to Cranfield et al. (2012), has economic, social, environmental, and health benefits.

\section{Conclusions}

According to the results, the food choice motivations of Hungarian consumers in the first wave of COVID-19 changed particularly in relation to the shelf life of the products and their 
packaging. During the period under review, the excellent taste of products and constantly high quality associated with the selected products maintained their leading position. As a result of the closures, the importance of popular, usual brand declined; it can be concluded that consumers, if they experience a crisis, are more likely to give up their usual brands and products. Convincing advertising was not important to participants either before the study period or during the first closure period. This result was also supported by factor analysis. Customer motivational factors were divided into four well-distinguished factors, which we referred to as: Healthy, domestic, and environmentally friendly choices; Usual taste and quality; Reasonable price; Shelf life. From the results of the study with the value of $65.093 \%$, it can be concluded that only a quarter of the Hungarian population is characterized by health- and environment-conscious choices and the preference for buying food of domestic origin. Nearly $20 \%$ of the population lost their income or their income fell significantly during the period of restrictions, while slightly more than $20 \%$ expect their household income to decline in the future. Accordingly, it can be assumed that the influencing factors related to food prices will come to the fore in the future.

The limitation of the study is the lack of study models. For the sake of comprehensive research, it would therefore be necessary to associate a model or models with the study, which would facilitate comparison with research results on a similar topic.

Financial Support: This work was supported by the EFOP-3.6.1-16-2016-00022 project. The project is co-financed by the European Union and the European Social Fund.

Conflict of Interest: The authors declare no conflict of interest.

Authorship: Conceptualization, T.M., Z.SZ., E.A., GY.K., D.SZ., E.K.; Methodology, T-M., Z.SZ.; Formal Analysis, T.M., Z.SZ., GY.K., D.SZ.; Investigation, Z.SZ., E.A., E.K.; Writing - Original Draft Preparation, T.M., Z.SZ., E.A., GY.K., D.SZ., E.K.; Writing - Review \& Editing, T.M., Z.SZ., E.K. All authors have read and agreed to the published version of the manuscript.

Ethical Standards Disclosure: This study was conducted according to the guidelines laid down in the Declaration of Helsinki and all procedures involving human subjects were approved by the Research Ethics Committee at the University of Debrecen, Faculty of 
Economics and Business (approval number: GTKDH/76/2021). Verbal informed consent was obtained from all subjects. Verbal consent was witnessed and formally recorded.

\section{References}

ANGLÉ, S., ENGBLOM, J., ERIKSSON, T., KAUTIAINEN, S., SAHA, M.-T., LINDFORS, P., LEHTINEN, M. \& RIMPELÄ, A. 2009. Three factor eating questionnaire-R18 as a measure of cognitive restraint, uncontrolled eating and emotional eating in a sample of young Finnish females. International Journal of Behavioral Nutrition and Physical Activity, 6, 1-7.

ARES, G., GIMÉNEZ, A. \& DELIZA, R. 2010. Influence of three non-sensory factors on consumer choice of functional yogurts over regular ones. Food quality and preference, 21, 361-367.

ARORA, N., CHARM, T., GRIMMELT, A., ORTEGA, M., ROBINSON, K., SEXAUER, C. \& YAMAKAWA, N. 2020. A global view of how consumer behavior is changing amid COVID-19. Mcknsey and Company. July. Retrieved on from https://www. mckinsey. com/ /media/McKinsey/Business\% 20Functions/Marketing\% 20and\% 20Sales/Our\% 20Insights/A\% 20global\% 20view\% 20of\% 20how\% 20consumer\% 20behavior\% 20is\% 20changing\% 20amid\% 20COVID, 20.

ATALAN, A. 2020. Is the lockdown important to prevent the COVID-19 pandemic? Effects on psychology, environment and economy-perspective. Annals of medicine and surgery, 56, 38-42.

BECH-LARSEN, T., GRUNERT, K. G. \& POULSEN, J. 2001. The acceptance of functional foods in Denmark, Finland and the United States: A study of consumers' conjoint evaluations of the qualities of functional foods and perceptions of general health factors and cultural values. University of Aarhus, Aarhus School of Business, The MAPP Centre.

BRUNNER, M. \& SÜB, H.-M. 2005. Analyzing the reliability of multidimensional measures: An example from intelligence research. Educational and Psychological Measurement, $65,227-240$.

CHONG, M. F.-F., AYOB, M. N. I. M., CHONG, K. J., TAI, E.-S., KHOO, C. M., LEOW, M. K.-S., LEE, Y. S., THAM, K. W., VENKATARAMAN, K. \& MEANEY, M. J. 2016. Psychometric analysis of an eating behaviour questionnaire for an overweight and obese Chinese population in Singapore. Appetite, 101, 119-124. 
CHUI, H., BRYANT, E., SARABIA, C., MASKEEN, S. \& STEWART-KNOX, B. 2019. Burnout, eating behaviour traits and dietary patterns. British Food Journal.

CRANFIELD, J., HENSON, S. \& BLANDON, J. 2012. The effect of attitudinal and sociodemographic factors on the likelihood of buying locally produced food. Agribusiness, 28, 205-221.

CRONBACH, L. J. 1951. Coefficient alpha and the internal structure of tests. psychometrika, $16,297-334$.

CZEGLÉDI, E. \& URBÁN, R. 2010. Hungarian adaptation of three-factor eating Questionnaire revised 21-item. Magyar Pszichológiai Szemle, 65, 463-494.

DAVIS, C., PATTE, K., LEVITAN, R., REID, C., TWEED, S. \& CURTIS, C. 2007. From motivation to behaviour: a model of reward sensitivity, overeating, and food preferences in the risk profile for obesity. Appetite, 48, 12-19.

DE LAUZON, B., ROMON, M., DESCHAMPS, V., LAFAY, L., BORYS, J.-M., KARLSSON, J., DUCIMETIERE, P. \& CHARLES, M. A. 2004. The Fleurbaix Laventie Ville Sante (FLVS) study group: the three-factor eating questionnaire-R18 is able to distinguish among different eating patterns in a general population. $J$. Nutr, 2380, 2372-2004.

DE MEDEIROS, A. C. Q., YAMAMOTO, M. E., PEDROSA, L. F. C. \& HUTZ, C. S. 2017. The Brazilian version of the three-factor eating questionnaire-R21: psychometric evaluation and scoring pattern. Eating and Weight Disorders-Studies on Anorexia, Bulimia and Obesity, 22, 169-175.

DONG, E., DU, H. \& GARDNER, L. 2020. An interactive web-based dashboard to track COVID-19 in real time. The Lancet infectious diseases, 20, 533-534.

EIT-FOOD. 2020. COVID-19 Impact on Consumer Food Behaviours in Europe. Available: https://www.eitfood.eu/news/post/eit-food-reportreveals-lasting-impact-of-covid-19pandemic-on-european-food-behaviours [Accessed 2021.03.17.].

EY-FUTURE-CONSUMER-INDEX. 2020. Four consumer behavior trends emerge during the COVID-19 pandemic. Available: https://www.ey.com/en gl/news/2020/04/fourconsumer-behavior-trends-emerge-during-the-covid-19-pandemic-the-first-ey-futureconsumer-index-finds [Accessed 2020.05.16.].

FURST, T., CONNORS, M., BISOGNI, C. A., SOBAL, J. \& FALK, L. W. 1996. Food choice: a conceptual model of the process. Appetite, 26, 247-266.

GAGIĆ, S., JOVIČIĆ, A., TEŠANOVIĆ, D. \& KALENJUK, B. 2014. Motives for food choice among Serbian consumers. Економика пољопривреде, 61. 
GILL, J. \& JOHNSON, P. 2002. Research methods for managers, Sage.

GLANZ, K., BASIL, M., MAIBACH, E., GOLDBERG, J. \& SNYDER, D. 1998. Why Americans eat what they do: taste, nutrition, cost, convenience, and weight control concerns as influences on food consumption. Journal of the American Dietetic Association, 98, 1118-1126.

GRUNERT, K. G., BECH-LARSEN, T. \& BREDAHL, L. 2000. Three issues in consumer quality perception and acceptance of dairy products. International Dairy Journal, 10, 575-584.

GRUNERT, K. G., DEAN, M., RAATS, M. M., NIELSEN, N. A. \& LUMBERS, M. 2007. A measure of satisfaction with food-related life. Appetite, 49, 486-493.

GRUNERT, K. G. \& WILLS, J. M. 2007. A review of European research on consumer response to nutrition information on food labels. Journal of public health, 15, 385-399.

GÜNEY, O. I. \& SANGÜN, L. 2021. How COVID-19 affects individuals' food consumption behaviour: a consumer survey on attitudes and habits in Turkey. British Food Journal.

HCSO, T. S. 2019a. Time series of annual data - Population, vital events/1.2.Population by type of settlement, 1 January (1980-2019), 1.3.Population by sex and age, 1 January (19802019). In Hungarian Central Statistical Office: 2019a.

HCSO, T. S. 2019b. Time series of annual, regional statistics - Population, vital events/6.1.1.Resident population by sex, 1 January (2001-2018). In Hungarian Central Statistical Office: 2019.

HCSO, T. S. 2021. Retail trade by type of business, monthly, quarterly (January 2017 - May 2021). In Hungarian Central Statistical Office: 2021.

HOBBS, J. E. 2020. Food supply chains during the COVID-19 pandemic. Canadian Journal of Agricultural Economics/Revue canadienne d'agroeconomie, 68, 171-176.

HYLAND, M. E., IRVINE, S. H., THACKER, C., DANN, P. L. \& DENNIS, I. 1989. Psychometric analysis of the Stunkard-Messick Eating Questionnaire (SMEQ) and comparison with the Dutch Eating Behavior Questionnaire (DEBQ). Current Psychology, 8, 228-233.

IFIC, I. F. I. C. F. 2021. 2021 Food \& Health Survey: Pandemic Food Habits Start to Wane While Positive Approaches to Diet and Health Grow. Available: https://www.globenewswire.com/news-release/2021/05/19/2232648/0/en/2021-FoodHealth-Survey-Pandemic-Food-Habits-Start-to-Wane-While-Positive-Approaches-toDiet-and-Health-Grow.html [Accessed 2021.06.10. ]. 
JANUSZEWSKA, R., PIENIAK, Z. \& VERBEKE, W. 2011. Food choice questionnaire revisited in four countries. Does it still measure the same? Appetite, 57, 94-98.

KARLSSON, J., PERSSON, L.-O., SJÖSTRÖM, L. \& SULLIVAN, M. 2000. Psychometric properties and factor structure of the Three-Factor Eating Questionnaire (TFEQ) in obese men and women. Results from the Swedish Obese Subjects (SOS) study. International journal of obesity, 24, 1715-1725.

KAVAZIDOU, E., PROIOS, M., LIOLIOS, I., DOGANIS, G., PETROU, K., TSATSOULIS, A. \& TSILIGIROGLOU-FACHANTIDOU, A. 2012. Structure validity of the threefactor eating questionnaire-R18 in Greek population.

KELLER, V., DERNÓCZY-POLYÁK, A. \& ERCSEY, I. 2016. Adaptation possibilities of the three factor eating questionnaire in the field of marketing research - differences based on gender and generation. Hung. J. Nutr. Market., 3-20.

KÖSTER, E. P. 2009. Diversity in the determinants of food choice: A psychological perspective. Food quality and preference, 20, 70-82.

LAPPALAINEN, R., KEARNEY, J. \& GIBNEY, M. 1998. A pan EU survey of consumer attitudes to food, nutrition and health: an overview. Food quality and Preference, 9, 467-478.

LONNEKER, J. Psychological impacts of health claims on consumer perception and behaviour. ILSI international symposium on functional foods in Europe, 2007.

MARINKOVIĆ, V. \& LAZAREVIĆ, J. 2021. Eating habits and consumer food shopping behaviour during COVID-19 virus pandemic: insights from Serbia. British Food Journal.

MARKOVINA, J., STEWART-KNOX, B. J., RANKIN, A., GIBNEY, M., DE ALMEIDA, M. D. V., FISCHER, A., KUZNESOF, S. A., POÍNHOS, R., PANZONE, L. \& FREWER, L. J. 2015. Food4Me study: Validity and reliability of Food Choice Questionnaire in 9 European countries. Food quality and preference, 45, 26-32.

MARTY, L., DE LAUZON-GUILLAIN, B., LABESSE, M. \& NICKLAUS, S. 2021. Food choice motives and the nutritional quality of diet during the COVID-19 lockdown in France. Appetite, 157, 105005.

MATTIOLI, A. V., PUVIANI, M. B., NASI, M. \& FARINETTI, A. 2020. COVID-19 pandemic: the effects of quarantine on cardiovascular risk. European journal of clinical nutrition, 74, 852-855.

MENRAD, K. 2003. Market and marketing of functional food in Europe. Journal of food engineering, 56, 181-188. 
MILOŠEVIĆ, J., ŽEŽELJ, I., GORTON, M. \& BARJOLLE, D. 2012. Understanding the motives for food choice in Western Balkan Countries. Appetite, 58, 205-214.

MOREIRA, P., ALMEIDA, L., SAMPAIO, D. \& ALMEIDA, M. D. V. 1998. Validação de uma escala para avaliação do comportamento alimentar de jovens universitários saudáveis. Revista Ibero-Americana de Diagnóstico e Avaliação Psicológica, 6, 125136.

MOSTAFAVI, S.-A., AKHONDZADEH, S., MOHAMMADI, M. R., ESHRAGHIAN, M. R., HOSSEINI, S., CHAMARI, M. \& KESHAVARZ, S. A. 2017. The reliability and validity of the persian version of three-factor eating questionnaire-R18 (TFEQ-R18) in overweight and obese females. Iranian journal of psychiatry, 12, 100.

PATTERSON, N. Exploring consumer attitudes. Taste versus convenience and health-What do consumers really want. Proceedings of the third functional food net meeting, 2006.

RENNER, B., SPROESSER, G., STROHBACH, S. \& SCHUPP, H. T. 2012. Why we eat what we eat. The Eating Motivation Survey (TEMS). Appetite, 59, 117-128.

ROBERFROID, M. B. 2000. Prebiotics and probiotics: are they functional foods? The American journal of clinical nutrition, 71, 1682S-1687S.

RODRÍGUEZ-PÉREZ, C., MOLINA-MONTES, E., VERARDO, V., ARTACHO, R., GARCÍA-VILLANOVA, B., GUERRA-HERNÁNDEZ, E. J. \& RUÍZ-LÓPEZ, M. D. 2020. Changes in dietary behaviours during the COVID-19 outbreak confinement in the Spanish COVIDiet study. Nutrients, 12, 1730.

ROININEN, K., LÄHTEENMÄKI, L. \& TUORILA, H. 1999. Quantification of consumer attitudes to health and hedonic characteristics of foods. Appetite, 33, 71-88.

ROMON, M., LOMMEZ, A., TAFFLET, M., BASDEVANT, A., OPPERT, J. M., BRESSON, J. L., DUCIMETIERE, P., CHARLES, M. A. \& BORYS, J. M. 2009. Downward trends in the prevalence of childhood overweight in the setting of 12-year school-and community-based programmes. Public health nutrition, 12, 1735-1742.

ROOS, E., LEHTO, R. \& RAY, C. 2012. Parental family food choice motives and children's food intake. Food Quality and Preference, 24, 85-91.

SAHER, M., ARVOLA, A., LINDEMAN, M. \& LÄHTEENMÄKI, L. 2004. Impressions of functional food consumers. Appetite, 42, 79-89.

SALLEH, M. M., ALI, S. M., HARUN, E. H., JALIL, M. A. \& SHAHARUDIN, M. R. 2010. Consumer's perception and purchase intentions towards organic food products: Exploring attitude among academician. Canadian Social Science, 6, 119-129. 
SANTE, F. L. V. 2004. Study Group. The Three-Factor Eating Questionnaire-R 18 is able to distinguish among different eating patterns in a general population. J Nutrition, 134, 2372-80.

SERREM, K., DUNAY, A., SERREM, C., ATUBUKHA, B., OLÁH, J. \& ILLÉS, C. B. 2020. Paucity of nutrition guidelines and nutrient quality of meals served to kenyan boarding high school students. Sustainability, 12, 3463.

SHEN, W., LONG, L. M., SHIH, C.-H. \& LUDY, M.-J. 2020. A humanities-based explanation for the effects of emotional eating and perceived stress on food choice motives during the COVID-19 pandemic. Nutrients, 12, 2712.

SOÓS, G. 2020. Az élelmiszer-fogyasztói szokások változása a COVID-19 vírus megjelenéséhez kapcsolódóan Magyarországon. Marketing \& Menedzsment, 54, 15-27.

STEPTOE, A., POLLARD, T. M. \& WARDLE, J. 1995. Development of a measure of the motives underlying the selection of food: the food choice questionnaire. Appetite, 25, 267-284.

STRIEN, T., FRIJTERS, J., BERGERS, G. P. \& DEFARES, P. 1986. The Dutch Eating Behavior Questionnaire (DEBQ) for assessment of restrained, emotional, and external eating behavior. International Journal of Geographical Information Science.

STUNKARD, A. J. \& MESSICK, S. 1985. The three-factor eating questionnaire to measure dietary restraint, disinhibition and hunger. Journal of psychosomatic research, 29, 7183.

SZAKÁLY, Z., KONTOR, E., KOVÁCS, S., POPP, J., PETÖ, K. \& POLERECZKI, Z. 2018. Adaptation of the Food Choice Questionnaire: the case of Hungary. British Food Journal.

SZAKÁLY, Z., KOVÁCS, B., SZAKÁLY, M., T NAGY-PETÖ, D., GÁL, T. \& SOÓS, M. 2020. Examination of the eating behavior of the hungarian population based on the tfeqr21 model. Nutrients, 12, 3514.

TISON, G. H., AVRAM, R., KUHAR, P., ABREAU, S., MARCUS, G. M., PLETCHER, M. J. \& OLGIN, J. E. 2020. Worldwide effect of COVID-19 on physical activity: a descriptive study. Annals of internal medicine, 173, 767-770.

URALA, N. \& LÄHTEENMÄKI, L. 2003. Reasons behind consumers' functional food choices. Nutrition \& Food Science.

VERBEKE, W. 2006. Functional foods: Consumer willingness to compromise on taste for health? Food quality and preference, 17, 126-131. 
YOUNG, J. 2000. Functional foods and the European consumer. Special publication-royal society of chemistry, 248, 75-81. 
Table I. Factors influencing purchase and their measurement $(\mathrm{N}=3000)$

\begin{tabular}{|l|c|}
\hline \multicolumn{1}{|c|}{ Factors influencing purchase } & \\
\hline Constantly high quality & \\
\hline Flavours associated with the product & \\
\hline Popular and usual brand & $\begin{array}{c}\text { A scale from 1-5, where 1 - not } \\
\text { important at all; } 5 \text { - extremely } \\
\text { important. }\end{array}$ \\
\hline Convincing advertisement & \\
\hline Favourable price & \\
\hline Integration into healthy diet & \\
\hline Discount price & \\
\hline Bhe food was produced in Hungary & \\
\hline Environmentally-friendly packaging & \\
\hline The product is packaged & \\
\hline Shelf life of the food & \\
\hline Local product/food from small farms & \\
\hline It has trademark & \\
\hline
\end{tabular}


Table II. Distribution of the sample according to the most important background variables (N $=3000$ ) and population composition according to representative variables

\begin{tabular}{|c|c|c|c|}
\hline Background variables & \multicolumn{2}{|c|}{ Sample distribution } & \multirow{2}{*}{$\begin{array}{c}\begin{array}{c}\text { Population } \\
\text { distribution }^{\mathbf{1}}\end{array} \\
52.2 \\
\end{array}$} \\
\hline Female & 1587 & 52.9 & \\
\hline Male & 1413 & 47.1 & 47.8 \\
\hline $18-29$ & 507 & 16.9 & 17.2 \\
\hline $30-39$ & 483 & 16.1 & 16.0 \\
\hline $40-59$ & 1044 & 34.8 & 34,7 \\
\hline $60-$ & 966 & 32.2 & 32.1 \\
\hline Budapest & 1059 & 35.3 & \\
\hline Other towns & 1530 & 51.0 & \\
\hline Village & 411 & 13.7 & \\
\hline Central Hungary & 1515 & 50.5 & \\
\hline Southern Great Plain & 282 & 9.4 & \\
\hline Northern Great Plain & 267 & 8.9 & \\
\hline Northern Hungary & 261 & 8.7 & \\
\hline Central Transdanubia & 252 & 8.4 & \\
\hline Western Transdanubia & 243 & 8.1 & \\
\hline Southern Transdanubia & 180 & 6.0 & \\
\hline Primary school & 36 & 1.2 & \\
\hline Vocational school & 219 & 7.3 & \\
\hline High school & 984 & 32.8 & \\
\hline Higher education & 1761 & 58.7 & \\
\hline Can live on it but can save little & 1215 & 40.5 & \\
\hline Can live on it very well and can also save & 993 & 33.1 & \\
\hline Just enough to live on but cannot save & 624 & 20.8 & \\
\hline Sometimes cannot make ends meet & 78 & 2.6 & \\
\hline Have regular financial problems & 27 & 0.9 & \\
\hline Not known/No answer & 63 & 2.1 & \\
\hline Mostly health conscious & 1564 & 52.1 & \\
\hline Health-conscious and not health-conscious & 834 & 27.8 & \\
\hline Very health conscious & 296 & 9.9 & \\
\hline Mostly not health conscious & 209 & 7.0 & \\
\hline Not health conscious at all & 67 & 2.2 & \\
\hline Not known/No answer & 30 & 1.0 & \\
\hline Mostly environmentally conscious & 1723 & 57.4 & \\
\hline Both environmentally conscious and not & 621 & 20.7 & \\
\hline Very environmentally conscious & 469 & 15.6 & \\
\hline Mostly not environmentally conscious & 141 & 4.7 & \\
\hline Not environmentally conscious at all & 26 & 0.9 & \\
\hline Not known/No answer & 20 & 0.7 & \\
\hline
\end{tabular}

Note: 1 Source of data: (HCSO, 2019a, HCSO, 2019b) 
Table III. Importance of purchasing factors when buying food before coronavirus $(\mathrm{N}=3000)$

\begin{tabular}{|c|c|c|c|c|}
\hline \multirow[b]{2}{*}{ Purchasing factors } & \multicolumn{4}{|c|}{ Statistical indicator } \\
\hline & Mean $^{1}$ & $\begin{array}{l}\text { Standard } \\
\text { deviation }\end{array}$ & $\begin{array}{c}\text { Relative } \\
\text { standard } \\
\text { deviation, } \\
\%\end{array}$ & Skewness \\
\hline 1. Flavours associated with the product & 4.35 & 0.752 & 17.29 & -1.415 \\
\hline 2. Constantly high quality & 4.01 & 0.895 & 22.32 & -0.876 \\
\hline 3. Popular and usual brand & 3.92 & 0.936 & 23.88 & -0.768 \\
\hline 4. Favourable price & 3.85 & 0.977 & 25.38 & -0.768 \\
\hline 5. Integration into a healthy diet & 3.83 & 1.052 & 27.47 & -0.790 \\
\hline 6. Shelf life of the food & 3.55 & 1.081 & 30.45 & -0.425 \\
\hline 7. Discount price & 3.52 & 1.109 & 31.51 & -0.480 \\
\hline 8. The food was produced in Hungary & 3.41 & 1.252 & 36.72 & -0.448 \\
\hline 9. Local product/food from small farm & 3.05 & 1.277 & 41.88 & -0.101 \\
\hline 10. Family-friendly packaging & 3.04 & 1.220 & 40.13 & -0.115 \\
\hline 11. It has trademark & 2.90 & 1.291 & 44.52 & 0.003 \\
\hline 12. Bio/ecological origin & 2.66 & 1.238 & 46.54 & 0.175 \\
\hline 13. The product is packaged & 2.54 & 1.246 & 49.06 & 0.364 \\
\hline 14. Convincing advertisement & 1.67 & 0.832 & 49.82 & 1.226 \\
\hline
\end{tabular}


Table IV. Importance of purchasing factors when buying food during coronavirus $(\mathrm{N}=3000)$

\begin{tabular}{|c|c|c|c|c|}
\hline \multirow[b]{2}{*}{ Purchasing factors } & \multicolumn{4}{|c|}{ Statistical indicator } \\
\hline & $\operatorname{Mean}^{1}$ & $\begin{array}{l}\text { Standard } \\
\text { deviation }\end{array}$ & $\begin{array}{c}\text { Relative } \\
\text { standard } \\
\text { deviation, } \\
\%\end{array}$ & Skewness \\
\hline 1. Flavours associated with the product & 4.14 & 0.848 & 20.48 & -1.055 \\
\hline 2. Constantly high quality & 3.98 & 0.943 & 23.69 & -0.952 \\
\hline 3. Shelf life of the food & 3.92 & 1.089 & 27.78 & -0.956 \\
\hline 4. Favourable price & 3.67 & 1.095 & 29.84 & -0.568 \\
\hline 5. Integration into healthy diet & 3.64 & 1.131 & 31.07 & -0.688 \\
\hline 6. Popular and usual brand & 3.59 & 1.080 & 30.08 & -0.549 \\
\hline 7. The food was produced in Hungary & 3.33 & 1.337 & 40.15 & -0.398 \\
\hline 8. Discount price & 3.33 & 1.233 & 37.02 & -0.321 \\
\hline 9. The product is packaged & 3.17 & 1.429 & 45.08 & -0.213 \\
\hline 10. Local product/food from small farm & 3.05 & 1.339 & 43.90 & -0.137 \\
\hline 11. Family-friendly packaging & 2.89 & 1.288 & 44.57 & 0.000 \\
\hline 12. It has trademark & 2.79 & 1.342 & 48.10 & 0.117 \\
\hline 13. Bio/ecological origin & 2.61 & 1.275 & 48.85 & 0.246 \\
\hline 14. Convincing advertisement & 1.56 & 0.821 & 52.63 & 1.555 \\
\hline
\end{tabular}

${ }^{I}$ Results were rated on a scale of 1 to 5 , with a value of 1 for 'Not important at all' and a value of 5 for 'very important'. 
Table V. Results of exploratory factor analysis $(\mathrm{N}=3000)$

\begin{tabular}{|c|c|c|c|c|}
\hline Factors influencing purchase & $\begin{array}{c}\text { Healthy, } \\
\text { domestic, and } \\
\text { environmentally- } \\
\text { friendly choice }\end{array}$ & $\begin{array}{l}\text { Usual } \\
\text { taste } \\
\text { and } \\
\text { quality }\end{array}$ & $\begin{array}{c}\text { Favourable } \\
\text { price }\end{array}$ & Shelf life \\
\hline Local product/food from small farm & 0.817 & & & \\
\hline The food was produced in Hungary. & 0.796 & & & \\
\hline Bio/ecological origin & 0.736 & & & \\
\hline Environmentally packaging & 0.704 & & & \\
\hline It has trademark & 0.685 & & & \\
\hline Integration into a healthy diet & 0.508 & & & \\
\hline \multicolumn{5}{|l|}{ Convincing advertisement } \\
\hline Flavours associated with the product & & 0.788 & & \\
\hline Constantly high quality & & 0.704 & & \\
\hline Popular, usual brand & & 0.523 & & \\
\hline Favourable price & & & 0.897 & \\
\hline Discount price & & & 0.791 & \\
\hline The product is packaged & & & & 0.925 \\
\hline Shelf life of the food & & & & 0.437 \\
\hline
\end{tabular}

Extraction method: Maximum Likelihood; Rotation method: Varimax rotation; Rotation converged in 5 iterations; $K M O=0.820$ (incredibly good); Bartlett: (Approx. Chi Sq.) 14477.24; (Sig.) 0;000; Communalities: 0.118-0.884; Cumulative explained variance: $65.093 ; N=3000$. 
Table VI. Reliability of the measuring instrument

\begin{tabular}{|l|c|c|}
\hline \multicolumn{1}{|c|}{ Factors } & Cronbach's alpha index & Composite reliability \\
\hline $\begin{array}{l}\text { Healthy, domestic, and } \\
\text { environmentally-friendly } \\
\text { choice }\end{array}$ & 0.878 & 0.891 \\
\hline Usual taste and quality & 0.716 & 0.608 \\
\hline Favourable price & 0.829 & 0.444 \\
\hline Shelf life & 0.595 & 0.210 \\
\hline
\end{tabular}

Source: based on own calculation. 